\title{
ClostridioIDes DIfFICILE INFECTION IN INTENSIVE CARE UNITS IN NURSING PRACTICE
}

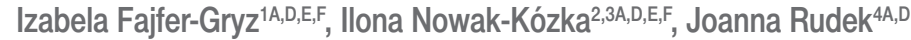

\author{
${ }^{1}$ Clinical Department of Angiology, University Hospital, Krakow, Poland \\ 2Department of Anaesthesiology and Intensive Therapy, University Hospital, Krakow, Poland \\ ${ }^{3}$ Department of Medical Education, Faculty of Medicine, Jagiellonian University Medical College, \\ Krakow, Poland \\ ${ }^{4}$ Critical and Chronic Care Solutions, 3M Healthcare Business Group, Poland
}

\section{Authors' contribution:}

A. Study design/planning • B. Data collection/entry • C. Data analysis/statistics $\bullet$ D. Data interpretation $\bullet$ E. Preparation of manuscript $\bullet$ F. Literature analysis/search $\bullet$ G. Funds collection

\author{
Address for correspondence: \\ Izabela Fajfer-Gryz \\ Clinical Department of Angiology \\ University Hospital \\ 22/2 Kłuszyńska St., 30-499 Krakow, Poland \\ e-mail: iza.fajfer@gmail.com \\ SUBMITTED: 25.02 .2020 \\ ACCEPTED: 28.03.2020 \\ DOl: https://doi.org/10.5114/ppiel.2020.96089
}

\begin{abstract}
Introduction: Patients hospitalised in intensive care units (ICU) are patients in severe health, who are at risk of serious hospital infections. Despite the development of medicine, developed procedures, management strategies, and high awareness of medical personnel, hospital infections are still a very big problem. One of the serious hospital infections is Clostridioides difficile, especially in ICU patients, which can even be fatal. The severity of the infection and its complications, which hamper treatment and care, are a challenge for the entire therapeutic team. At the same time, this infection is a major epidemiological threat and increases the cost of treatment. That is why the diagnosis of infection, the application of the recommended treatment, as well as the correct prevention are so important. The basis for preventing the spread of $C$. difficile infection is hand hygiene, the use of personal protective equipment, patient isolation, maintenance of disinfection, infected patient care, education of visitors, and monitoring and recording of infections. Aim of the study: Discussing current data on treatment in the presence of $C$. difficile infection and describing problems faced by ICU medical personnel.

Conclusions: Following current recommendations for diagnosis and treatment and applying appropriate control procedures and methods contributes to preventing the spread of $C$. difficile infection in intensive care units.

Key words: nursing care, recommendations, intensive care unit, Clostridioides difficile infection.
\end{abstract}

\section{INTRODUCTION}

Clostridioides difficile infection (CDI) develops in the large intestine, causing diarrhoea of varying severity - from mild diarrhoea to pseudomembranous colitis and toxic megacolon with intestinal perforation. C. difficile infection may lead to complications like partial or total surgical removal of the large intestine (colectomy), sepsis, and even death. Disruption of intestinal microflora after antimicrobial therapy has a decisive impact on the colonisation of the infection and the produced toxin. Transmission occurs in the faecal-oral route. Possible sources of infection include patients, hospital staff, visitors, medical equipment, and the hospital environment [1-6]. This review article discusses the literature and current guidelines for limiting the spread of CDI in a hospital setting. Most of the data were collected by analysing current Polish and foreign literature from PubMed (Medline).

\section{RISK FACTORS}

There are several risk factors for CDI:

- antibiotic therapy (long-term, multi-drug),

- patient age (> 65 years),
- long hospitalisations,

- hospitalisation in an intensive care units (ICU),

- immunodeficiency (acquired or congenital),

- co-morbidities (e.g. chronic renal failure requiring dialysis),

- steroid therapy,

- chemotherapy [1-11].

The main factor in the development of disease caused by $C$. difficile is antibiotic use. According to some authors, in $10-30 \%$ of cases of post-antibiotic use diarrhoea can be attributed to $C$. difficile $[12,13]$. This applies especially to broad-spectrum antibiotics that are active against anaerobic bacteria and to which C. difficile is resistant. C. difficile diarrhoea is most commonly caused by the following antibiotics: fluroquinolones, second- and third-generation cephalosporins, clindamycin, ampicillin, amoxicillin, and broad-spectrum penicillins with inhibitors (except for ticarcillin with clavulanate and piperacillin with tazobactam) $[1,3,4,14,15]$. It is important to remember that any antibiotic can cause $C$. difficile-associated diarrhoea.

Many studies have also shown a significant effect of proton pump inhibitors on the increase of CDI in patients receiving high-risk antibiotics $[8,16,17]$. 
Another significant problem in the treatment of patients is recurrent $\mathrm{CDI}$, which may be caused by persistent resistant spores in the colon, an impaired immune response, or a change in normal intestinal microflora [18-20]. The recurrence of the disease occurs in $20-25 \%$ of patients [1].

Particular attention should be paid to critically ill patients who are at increased risk of developing diarrhoea. The disease makes treatment difficult, prolongs hospitalisation, but also exposes the patient to serious complications [21-23].

\section{DIAGNOSIS}

According to the European Centre for Disease Prevention and Control (ECDC), for the diagnosis of CDI one of the following conditions should be met:

- loose stools or the presence abnormal dilation of the large intestine and positively confirmed through microbiological testing for the presence of toxins $A$ and/or $B$, or the presence of a $C$. difficile strain producing the toxin(s) detected in the stool,

- the presence of pseudomembranous colitis determined in endoscopic examination,

- the presence of pseudomembranous colitis determined in histopathological examination [24].

Scales like the Bristol Stool Form Scale (BSF) or the Bliss Stool Chart may be useful in the assessment of stools; although, unfortunately, they are currently rarely used in ICUs $[25,26]$. Apart from diarrhoea, symptoms of CDI may include the following: severe abdominal pain, fever, nausea, and vomiting. The above symptoms may lead to hypovolaemia, which is especially dangerous in ICU patients.

Diagnostic testing for CDI should be ordered based on the above criteria. Routine testing in ICU patients or medical personnel is not recommended due to a high incidence of asymptomatic carriers. It is also not recommended to perform repeated tests during the same episode of diarrhoea, or cure tests. A positive $C D I$ test result should be immediately reported to the hospital infection control unit [27, 28].

The material used in testing for $C$. difficile is a liquid, unformed stool sample. The sample, collected in a sterile test tube (approximately 3-5 ml), should be delivered to the appropriate laboratory within two hours of collection, at room temperature. If it is not possible to deliver the material in such a short time, samples should be stored in a refrigerator (also during transport to the laboratory, which is not always obvious) at $4^{\circ} \mathrm{C}$. The material can be stored for up to 72 hours in such a temperature, and if necessary, the sample can be frozen to $-80^{\circ} \mathrm{C}$. It is important to remember that storing the material in a refrigerator reduces the number of vegetative cells. Further handling of the sample depends on the type of analysis to be performed [29-31].
The currently performed CDI diagnostic tests are screening tests that allow determination of the suspected infection, including: detecting the bacterial strain, or both toxins (A and B), or one of them, directly in a stool sample. The available CDI diagnostic tests are based on: toxigenic culture (TC), molecular tests (nucleic acid amplification test - NAAT), testing for glutamate dehydrogenase (an enzyme produced in large quantities by all toxin-releasing strains, as well as by strains that do not release toxins, making it an excellent diagnostic marker), cytotoxicity tests (CCNA), and enzyme immunoassays towards toxins $A$ and $B[3,27]$.

\section{EPIDEMIOLOGY}

The spread of CDI is a serious epidemiological problem in a hospital setting. This is related to the emergence of new strains that are resistant to multiple antibiotics [3, 32, 33]. The B1/NAP1/027 strain is particularly virulent, causing infections with a much more severe clinical course and higher mortality than prior strains. It is characterised by a high degree of resistance to antibiotics, increased ability to form spores, higher production of toxins $A$ and B (16 and 23 times more than other strains, respectively), as well as production of an additional binary toxin $[3,34]$. In the conducted studies, an increase in the incidence of $C$. difficile infections caused by the NAP1 strain was found in several hospitals; for example, in 2005 there was an increase from 10 cases to 33 cases per 100,000 patients [3, 32]. A study conducted in 2014 in 20 EU countries found an average of seven cases of CDI per 10,000 patient days of hospitalreation [3, 35], while in 2016, according to the ECDC, there were already 7.4 cases per 10,000 patient days $[6,36]$.

According to data collected by the Polish National Institute of Public Health - National Institute of Hygiene (Narodowy Instytut Zdrowia Publicznego - Państwowy Zakład Higieny - NIZP-PZH), the incidence of CDI is growing also in Poland - in 2016 there was an average of 22.7 cases per 100,000 inhabitants, while in 2017 this rate was already at 30.4 cases per 100,000 inhabitants [37]. As a result of research conducted in 2011-2013, covering 13 cities in Poland, it was found that the most common cause of CDI was strain B1/NAP1/027, which accounted for $62 \%$ compared to other strains [38]. However, the same type of strain in 2017 caused $80 \%$ of cases in Silesia [39].

\section{TREATMENT}

According to guidelines issued by the Infectious Diseases Society of America (IDSA) and Society for Healthcare Epidemiology of America (SHEA), CDI 
Table 1. Summary of key aspects of $C$. difficile infection in ICUs in nursing practice

\begin{tabular}{|c|c|}
\hline Policy aspect & Nursing intervention \\
\hline $\begin{array}{l}\text { Diagnosis and } \\
\text { care }\end{array}$ & $\begin{array}{l}\text { - Assess the frequency of defecation } \\
\text { and measure stool amounts and } \\
\text { characteristics } \\
\text { - Assess the history of antibiotic use } \\
\text { - Monitor vital signs - temperature, blood } \\
\text { pressure, heart rate, urine output, and } \\
\text { mental status } \\
\text { - Assess signs and symptoms (severe } \\
\text { abdominal pain, fever, nausea, vomiting, } \\
\text { hypovolaemia) } \\
\text { - Obtain stool specimens according to the } \\
\text { procedure } \\
\text { - Promote comfort and maintain skin } \\
\text { integrity - use of a closed system for } \\
\text { controlled stool collection, proper skin } \\
\text { care, use of protective and barrier } \\
\text { creams and lotions } \\
\text { - Prevention of patients' emotional stress } \\
\text { associated with being in isolation }\end{array}$ \\
\hline $\begin{array}{l}\text { Isolation } \\
\text { precautions }\end{array}$ & $\begin{array}{l}\text { - Single-occupancy rooms for patients } \\
\text { with CDI } \\
\text { - Patients hospitalised in multi-bed } \\
\text { rooms - recommended that } \\
\text { a dedicated isolation space be separated } \\
\text { within the patient's room } \\
\text { - Use disposable equipment } \\
\text { - Hand hygiene - soap or chlorhexidine- } \\
\text { based sanitisers should be used } \\
\text { - Personal protective equipment: } \\
\text { disposable gloves, gowns, disposable } \\
\text { protective clothing } \\
\text { - Recommended chlorine-based } \\
\text { preparations for disinfection of surfaces } \\
\text { - Education of visitors }\end{array}$ \\
\hline $\begin{array}{l}\text { Pharmacotherapy } \\
\text { and faecal } \\
\text { microbiota } \\
\text { transplantation }\end{array}$ & $\begin{array}{l}\text { - Traditional pharmacological treatment } \\
\text { of CDI should be started only after } \\
\text { testing for C. difficile is completed } \\
\text { - Pharmacological treatment according to } \\
\text { guidelines (vancomycin or fidaxomicin } \\
\text { or metronidazole) } \\
\text { - Patients should be monitored for } \\
\text { vancomycin resistance } \\
\text { - FMT recommended after a third } \\
\text { recurrence of the infection } \\
\text { - Prepare the FMT stool: } 200-300 \text { g stool } \\
\text { from a healthy donor, mixed with } \\
\text { physiological saline or water to make } \\
\text { a liquid slurry, filtered and then instilled } \\
\text { in the upper or lower part of the } \\
\text { gastrointestinal tract } \\
\text { - Patients' and relatives' education and } \\
\text { psychological support }\end{array}$ \\
\hline
\end{tabular}

should be treated with orally administered vancomycin (dose $125 \mathrm{mg}$ four times per day) or fidaxomicin (dose $200 \mathrm{mg}$ twice a day) for 10 days [27]. If there is no improvement within 48 hours, the dose of vancomycin can be increased up to $500 \mathrm{mg}$ four times per day [40]. In cases of mild infections or if vancomycin or fidaxomicin is not available, metroni- dazole (500 mg three times daily for 10 days) may be administered $[4,41]$. Due to its cumulative and neurotoxic effects metronidazole treatment should not be repeated or prolonged. In cases of fulminant CDI with hypotension or shock, obstruction, or megacolon, additional rectal administration of vancomycin (500 mg every six hours) should be considered, and, additionally, metronidazole treatment should be also introduced [27]. In patients with recurrent infections, intestinal faecal microbiota transplantation (FMT) is recommended. Treatment involves administering a human stool from a healthy donor to the intestine of a sick patient to restore normal intestinal microflora. The most common methods of stool administration are retention enema, colonoscopy, and infusion through a nasogastric tube. Faecal transplant is a low-cost, low-risk, highly effective treatment [42].

\section{PREVENTION}

A basic and, at the same time, the most difficult (especially in ICU environments) means of reducing the risk of $C$. difficile infections is to reduce the number of antibiotics used.

The rapid spread of $C$. difficile infections is highly dangerous for patients in ICUs, causing deterioration of health through severe complications and even death.

Due to frequent infectious complications, and the resulting treatment with broad-spectrum antibiotics, these patients are particularly vulnerable to the spread of drug-resistant microorganisms. Nurses who have direct contact with the patient, perform many activities with the patient (e.g. body toilet), or take part in many procedures and tests (e.g. in the pharmacotherapy or FMT) play a significant role in preventing the transmission of infections. Table 1 is a summary of key aspects of CDI in ICU in nursing practice. In order to prevent $C$. difficile infections, it is very important to take appropriate measures, which include:

- hand hygiene and use of personal protective equipment,

- patient isolation,

- maintaining cleanliness with disinfection,

- infected patient care,

- education of visitors,

- surveillance.

\section{HAND HYGIENE AND PERSONAL PROTECTIVE EQUIPMENT}

According to the World Health Organisation (WHO), the key element in prevention of hospital infections is proper hand hygiene and the application of the "five moments for hand hygiene" rule: before touching a pa- 
tient, before clean/aseptic procedures, after body fluid exposure/risk, after touching a patient, and after touching the patient's surroundings [43]. It is estimated that the most common cause (60-90\%) of infections is the transmission of pathogens present on the hands of medical personnel [44].

According to current Centers for Disease Control and Prevention (CDC) recommendations, in the case of a patient with CDI, hand hygiene should be performed routinely and in endemic situations before and after contact with the patient and after removing gloves.

It is strongly recommended to perform hand hygiene, routinely and in endemic situations, through washing with soap under running water or disinfecting with an alcohol-based hand rub [3].

However, if there is an epidemiological outbreak or a high incidence rate of CDI, or in the case of direct contact with faecal flora, soap or chlorhexidine-based sanitisers should be used for hand hygiene [45]. Soap and/or chlorhexidine preparations remove spores more effectively compared to alcohol-based hand sanitisers. Additional barriers such as disposable gloves and gowns should also be used to reduce the spread of infection. Personal protective equipment should be used when entering the patient's room and during any activities performed with the patient and in their environment [3].

\section{PATIENT ISOLATION}

Contact isolation is aimed at preventing the spread of infections through direct contact (between staff and the patient, between patients, and between the environment and patients) and indirect contact (e.g. through shared equipment) [46].

In cases of suspicion or diagnosis of CDI, contact isolation of the patient (room with airlock) should be implemented. If the use of a single-patient room is not possible, especially in the ICU, where patients are often hospitalised in multi-bed rooms, it is recommended that a dedicated isolation space within the patients' room is separated [47]. In the case of isolation in multiple-patient rooms, it is strongly recommended by the IDSA and SHEA to separate patients with $C$. difficile from patients colonised simultaneously with various multiresistant microorganisms, e.g. MRSA (Staphylococcus aureus) and VRE (Enterococcus spp.) $[27,28]$. Unfortunately, according to the reports of the Polish Supreme Audit Office (Najwyższa Izba Kontroli, NIK) and studies performed in many centres in Poland, it appears that over $40 \%$ of all hospital infections, either recognised at admission or due to treatment complications, are recorded in patients hospitalised in ICUs $[48,49]$. This is why presumptive isolation of patients in whom C. difficile is suspected or while awaiting diagnostic test results is so important. Contact isolation should be continued for at least 48 hours after diarrhoea is resolved and can be maintained until the patient is discharged, especially if there is an increased incidence rate in the unit [3]. It is also advised that transport of CDI patients is limited, although this is often impossible in the case of patients in critical condition requiring proper imaging diagnostics. If a patient is discharged to another ward or to another hospital, thorough information should be provided by medical staff at discharge about the suspicion or diagnosis of CDI and the need to implement appropriate procedures [45, 49].

\section{MAINTAINING CLEANLINESS WITH DISINFECTION}

The spread of CDI is largely associated with the production of spores, which are resistant to external factors like drying, and low or high temperatures. Therefore, it is strongly recommended to use disposable equipment. Multiple-use patient-care equipment (blood pressure meter, pulse oximeter) can be dedicated for the patient infected with $C$. difficile - equipment after use should be decontaminated, for example, through sterilisation. Chlorine-based preparations are recommended for disinfection of surfaces. It is recommended that the patient's room is cleaned and disinfected every day, as well as surfaces and equipment from the patient's surroundings. Sporicidal agents should also be used for disinfection after patient discharge. Dirty personal and bed linen should be closed in a separate bag at the place of isolation [3, 45, 49].

\section{INFECTED PATIENT CARE}

In the case of diarrhoea, barrier preparations should be used, which form a protective layer and a screen between the skin and the liquid stool. In CDI spores are excreted in large quantities with faeces. Hence, proper care and maintenance of skin cleanliness in patients in critical condition are very important. The search for optimal solutions for care in patients with diarrhoea in intensive care units continues worldwide. Standards of conduct are aimed at creating safety for both the patient and the staff. One of the methods of nursing patients with diarrhoea in ICUs is the use of a closed system for controlled stool collection. The system consists of a soft, silicone sleeve, about $1.5 \mathrm{~m}$ long, equipped with a silicone, lowpressure balloon at one end, and at the other - with a flange for connecting to a collecting bag. The balloon is introduced through the anal sphincter so that it is in the rectal bubble. The system is easy to use. Its use reduces the risk of skin damage through effective control and drainage of liquid faeces. It protects the skin against the harmful effects of faecal enzymes that damage the epidermis, increasing the risk of infections and of appearance of wounds around the 
anus. Using a closed system for controlled stool collection also reduces the risk of cross-contamination, saves the work time of medical personnel, and limits the amount of used dressings. The system also allows accurate calculation of the amount of stool donated, which is important in critically ill patients, in whom diarrhoea may cause dehydration. Therefore, it is very important for these patients to keep a fluid balance card describing the amount of fluid intake and excretion. Skin care is another important element of care for patients with $C$. difficile. The skin performs one of the most important functions - a protective function. The possibility of skin damage associated with urinary and/or faecal incontinence (incontinence-associated dermatitis - IAD), in this case caused by $C$. difficile diarrhoea, requires appropriate care. Patient cleaning products require one-time use, wet towels with a balanced $\mathrm{pH}$ and containing dimethicone, having skin protective properties. For the prevention of IAD, it is recommended to use protective and barrier creams and lotions. These preparations form a transparent protective layer, which reduces the risk of dermatitis associated with the action of liquid stool [50-52].

\section{EDUCATION OF VISITORS}

Another important element in preventing the spread of $C$. difficile is educating the families and persons visiting a given patient. The very fact of a close person being hospitalised in an intensive care unit is very stressful, so it is worth explaining the rules of conduct to the family in a simple and approachable way. Most importantly, hand hygiene - showing the proper technique of hand washing using soap and water, putting on gloves and disposable protective clothing. The family should be shown how and where medical waste is segregated. It should be stressed that visitors should not sit on the bed of the patient, nor should they put their clothes or objects of everyday use (bags, phones, etc.) on the patient's linen or on the floor. It is not advisable that the patient be visited by children or older people when infected $[53,54]$.

\section{SURVEILLANCE}

Currently, one of the most important health policy goals is to prevent the increase of microorganism drug resistance by applying relevant antibiotic policy and monitoring and recording infections. The task of a Hospital Infections Control Team (Zespół Kontroli Zakażeń Szpitalnych - ZKZSZ) is to manage infection control. Active surveillance includes proper healthcare-associated surveillance with infections prevention and control, monitoring procedures, conducting internal training on proper hand hygiene and patient isolation, as well as controlling use of antibiotics [45, $49,55,56]$.
In intensive care units, discontinuation of antibiotics is difficult, if not impossible, due to the presence of various infections in one patient at the same time. In addition, studies found that about $10-30 \%$ of hospitalised patients, as well as a significant proportion of medical personnel, had asymptomatic $C$. difficile $[3,57]$, which may contribute to the spread of infection in the hospital $[58,59]$. All patients hospitalised in the ICUs with symptoms of: "acute abdomen" for no known reason, diarrhoea with increased leukocytosis, or after antibiotic therapy or after treatment with proton pump inhibitors, should be screened for infection [45].

It is also very important to control the implementation of guidelines and recommendations for treatment and procedures. It is equally important to conduct continuous internal training, both among young, inexperienced nursing staff who still have insufficient knowledge and are prone to make mistakes, as well as among senior nurses who should continuously update their knowledge [60].

\section{CONCLUSIONS}

Due to an increase in CDI incidence caused by CDI in ICUs, it is very important to quickly diagnose patients and implement appropriate treatment as well as proper monitoring and registration of infections.

Nurses play a key role in recognising the symptoms of infection and preventing the spread of $C$. difficile. Following procedures, meticulous hand hygiene, compliance with patient isolation protocols, and proper education of staff and visitors are the foundations for effective prevention of $C$. difficile transmission.

\section{Disclosure}

The authors declare no conflict of interest.

\section{References}

1. Bartnik W, Szczepanek M, Rymer W. Zakażenie Clostridiodes (Clostridium) difficile i rzekomobłoniaste zapalenie jelit. In: Gajewski P, Szczeklik A. Interna Szczeklika 2018. Medycyna Praktyczna 2018; 1072-1075.

2. Guh AY, Kutty PK. Clostridioides difficile Infection. Ann Intern Med 2018; 169: 49-64.

3. Martirosian G, Hryniewicz W, Ozorowski T, et al. Zakażenia Clostridioides (Clostridium) difficile: epidemiologia, diagnostyka, terapia, profilaktyka. Narodowy Instytut Leków, 2018. www.antybiotyki.edu.pl.

4. Leffler DA, Lamont JT. Clostridium difficile infection. N Engl J Med 2015; 373: 287-288.

5. Vesteinsdottir I, Gudlaugsdottir S, Einarsdottir R, et al. Risk factors for Clostridium difficile toxin-positive diarrhea: a population-based prospective case-control study. Eur J Clin Microbiol Infect Dis 2012; 31: 2601-2610.

6. Huang H, Wu S, Chen R, et al. Risk factors of Clostridium difficile infections among patients in a university hospital in Shanghai, China. Anaerobe 2014; 30: 65-69. 
7. Lee-Tsai YL, Luna-Santiago R, Demichelis-Gómez R, et al. Determining the risk factors associated with the development of Clostridium difficile infection in patients with hematological diseases. Blood Res 2019; 54: 120-124.

8. Barletta JF, El-Ibiary SY, Davis LE, et al. Proton Pump Inhibitors and the Risk for Hospital-Acquired Clostridium difficile Infection. Mayo Clin Proc 2013; 88: 1085-1090.

9. Loo VG, Bourgault AM, Poirier L, et al. Host and pathogen factors for Clostridium difficile infection and colonization. N Engl J Med 2011; 365: 1693-1703.

10. Tirath A, Tadros S, Coffin SL, et al. Clostridium difficile infection in dialysis patients. J Investig Med 2017; 65: 353-357.

11. Chaughtai S, Gandhi B, Chaughtai Z, et al. Clostridium difficile peritonitis: an emerging infection in peritoneal dialysis patients. Case Rep Med 2018; 2018: 3537283.

12. Gualtero SM, Abril LA, Camelo N, et al. Characteristics of Clostridium difficile infection in a high complexity hospital and report of the circulation of the NAP1/027 hypervirulent strain in Colombia. Biomedica 2017; 37: 466-472.

13. Guery B, Galperine T, Barbut F. Clostridioides difficile: diagnosis and treatments. BMJ 2019; 366: 14609.

14. Owens RC Jr, Donskey CJ, Gaynes RP, et al. Antimicrobialassociated risk factors for Clostridium difficile infection. Clin Infect Dis 2008; 46: 19-31.

15. Hensgens MP, Goorhuis A, Dekkers OM, et al. Time interval of increased risk for Clostridium difficile infection after exposure to antibiotics. J Antimicrob Chemother 2012; 67: 742-748.

16. King RN, Lager SL. Incidence of Clostridium difficile infections in patients receiving antimicrobial and acid-suppression therapy. Pharmacotherapy 2011; 31: 642-648.

17. Gordon D, Young LR, Reddy S, et al. Incidence of Clostridium difficile infection in patients receiving high-risk antibiotics with or without a proton pump inhibitor. J Hosp Infect 2016; 92: 173-177.

18. Barra-Carrasco J, Paredes-Sabja D. Clostridium difficile spores: a major threat to the hospital environment. Future Microbiol 2014; 9: 475-486.

19. Gómez S, Chaves F, Orellana MA. Clinical, epidemiological and microbiological characteristics of relapse and re-infection in Clostridium difficile infection. Anaerobe 2017; 48: 147-151.

20. Chilton $\mathrm{CH}$, Pickering DS, Freeman J. Microbiologic factors affecting Clostridium difficile recurrence. Clin Microbiol Infect 2018; 24: 476-482.

21. Czepiel J, Kędzierska J, Biesiada G, et al. Epidemiology of Clostridium difficile infection: results of a hospital-based study in Krakow, Poland. Epidemiol Infect 2015; 143: 3235-3243.

22. Ziółkowski G, Pawłowska I, Krawczyk L, et al. Antibiotic consumption versus the prevalence of multidrug-resistant Acinetobacter baumannii and Clostridium difficile infections at an ICU from 2014-2015. J Infect Public Health 2018; 11: 626-630.

23. Jasiak NM, Alaniz C, Rao K, et al. Recurrent Clostridium difficile infection in intensive care unit patients. Am J Infect Control 2016; 44: 36-40.

24. Dziennik Urzędowy Unii Europejskiej. 2018/945 z dnia 22 czerwca 2018 r. L 170/1.

25. Caroff DA, Edelstein PH, Hamilton K, et al. The Bristol stool scale and its relationship to Clostridium difficile infection. J Clin Microbiol 2014; 52: 3437-3439.

26. Zimmaro Bliss D, Dhamani KA, Savik K, et al. Tool to classify stool consistency: content validity and use by persons of diverse cultures. Nurs Health Sci 2003; 5: 115-121.

27. McDonald LC, Gerding DN, Johnson S, et al. Clinical practice guidelines for Clostridium difficile infection in adults and children: 2017 Update by the Infectious Diseases Society of America (IDSA) and Society for Healthcare Epidemiology of America (SHEA). Clin Infect Dis 2018; 66: 1-48.

28. Tschudin-Sutter S, Kuijper EJ, Durovic A, et al. Guidance document for prevention of Clostridium difficile infection in acute healthcare settings. Clin Microbiol Infect 2018; 24: 1051-1054.

29. Gateau C, Couturier J, Coia J, et al. How to: diagnose infection caused by Clostridium difficile. Clin Microbiol Infect 2018; 24: 463-468.

30. Barbut F, Surgers L, Eckert C, et al. Does a rapid diagnosis of Clostridium difficile infection impact on quality of patient management? Clin Microbiol Infect 2014; 20: 136-144.

31. Freeman J, Wilcox MH. The effects of storage conditions on viability of Clostridium difficile vegetative cells and spores and toxin activity in human faeces. J Clin Pathol 2003; 56: 126-128.

32. Kuijper EJ, Barbut F, Brazier JS, et al. Update of Clostridium difficile infection due to PCR ribotype 027 in Europe, 2008. Euro Surveill 2008; 13.

33. Nyč O, Pituch H, Matějková J, et al. Clostridium difficile PCR ribotype 176 in the Czech Republic and Poland. Lancet 2011; 377: 1407.

34. Pituch H, Bakker D, Kuijper E, et al. First isolation of Clostridium difficile PCR-ribotype 027/toxinotype III in Poland. Pol J Microbiol 2008; 57: 267-268.

35. Davies KA, Longshaw CM, Davis GL, et al. Underdiagnosis of Clostridium difficile across Europe: the European, multicentre, prospective, biannual, point-prevalence study of Clostridium difficile infection in hospitalised patients with diarrhoea (EUCLID). Lancet Infect Dis 2014; 14: 1208-1219.

36. ECDC: European surveillance of Clostridium difficile infections. Surveillance protocol version 2.3. Stockholm: ECDC 2017.

37. http://wwwold.pzh.gov.pl/oldpage/epimeld/2017/Ch_2017_ wstepne_dane.pdf

38. Pituch H, Obuch-Woszczatyński P, Lachowicz D, et al. Hospital-based Clostridium difficile infection surveillance reveals high proportions of PCR ribotypes 027 and 176 in different areas of Poland, 2011 to 2013. Euro Surveill 2015; 20.

39. Aptekorz M, Szczegielniak A, Wiechuła B, et al. Occurrence of Clostridium difficile ribotype 027 in hospitals of Silesia, Poland. Anaerobe 2017; 45: 106-113.

40. Baines SD, Chilton CH, Crowther GS, et al. Evaluation of antimicrobial activity of ceftaroline against Clostridium difficile and propensity to induce $C$. difficile infection in an in vitro human gut model. J Antimicrob Chemother 2013; 68: 1842-1849.

41. Ooijevaar RE, van Beurden YH, Terveer EM, et al. Update of treatment algorithms for Clostridium difficile infection. Clin Microbiol Infect 2018; 24: 452-462.

42. Boyle ML, Ruth-Sahd LA, ZhouZ. Fecal microbiota transplant to treat recurrent Clostridium difficile infections. Crit Care Nurse 2015; 35: 51-65.

43. WHO Guidelines on Hand Hygiene in Health Care: First Global Patient Safety Challenge Clean Care is Safer Care. World Health Organization 2009.

44. Fleischer M. Higiena rąk. Zakażenia Szpitalne 2014; 1: 11-13.

45. Hryniewicz W, Martirosian G, Ozorowski T. Zakażenia Clostridium difficile. Diagnostyka, terapia, profilaktyka. Narodowy Instytut Leków, Warszawa 2011.

46. Siegel JD, Rhinehart E, Jackson $M$, et al. Management of multidrug-resistant organisms in health care settings, 2006. Am J Infect Control 2007; 35: 165-193.

47. Gaszyński W. Zakażenia szpitalne w Oddziale Intensywnej Terapii. In: Denys A (ed.). Zakażenia szpitalne w wybranych oddziałach: Część II. Wolters Kluwer 2013; 257-301. 
48. https://www.nik.gov.pl/aktualnosci/zakazenia-w-szpitalachpowaznym-problemem.html.

49. Miętkiewicz S, Nowaczyk B. Profilaktyka i kontrola zakażeń na oddziałach anestezjologii i intensywnej terapii. In: Dyk D, Gutysz-Wojnicka A. Pielęgniarstwo anestezjologiczne i intensywnej terapii. PZWL, Warszawa 2018; 256-264.

50. Rudek J. Zamknięty system do kontrolowanej zbiórki stolca jako alternatywna metoda pielęgnacji pacjenta $z$ biegunką w oddziale intensywnej terapii. Forum Zakażeń 2014; 5: 7-15.

51. Van den Bussche K, Kottner J, Beele H, et al. Core outcome domains in incontinence-associated dermatitis research. J Adv Nurs 2018; 74: 1605-1617.

52. Beeckman D, Van Damme N, Schoonhoven I, et al. Interventions for preventing and treating incontinence-associated dermatitis in adults. Cochrane Database Syst Rev 2016; 11.

53. Alhmidi H, Cadnum JL, Piedrahita CT, et al. Evaluation of an automated ultraviolet-C light disinfection device and patient hand hygiene for reduction of pathogen transfer from interactive touchscreen computer kiosks. Am J Infect Control 2018; 46: 464-467.

54. Fletcher KR, Cinalli M. Identification, optimal management, and infection control measures for Clostridium difficileassociated disease in long-term care. Geriatr Nurs 2007; 28: 171-181.

55. Wieder-Huszla S. Monitorowanie zakażeń szpitalnych na oddziale intensywnej terapii medycznej. Ann Acad Med Stetin 2010; 56: 20-29.

56. Sierocka A, Cianciara M. Monitorowanie zakażeń szpitalnych. Prob Hig Epidemiol 2010; 91: 323-328.

57. Szczęsny A, Martirosian G. Epidemiologia zakażeń Clostridium difficile. Przegl Epidemiol 2002; 56: 49-56.

58. Caroff DA, Yokoe DS, Klompas M. Evolving insights into the epidemiology and control of Clostridium difficile in hospitals. Clin Infect Dis 2017; 65: 1232-1238.

59. Durovic A, Widmer AF, Tschudin-Sutter S. New insights into transmissions of Clostridium difficile infection - narrative review. Clin Microbiol Infect 2018; 24: 483-492.

60. Łoś I, Dziewulska J. Wiedza personelu pielęgniarskiego na temat Clostridium difficile. Aspekty Zdrowia i Choroby 2018; 3: 109-132. 